Development".]. Kharkiv, pp.125 - 127. 10. Kalicheva N.E. (2014). Problemy' ta perspekty`vy vprovadzhennya informacijny`x texnologij $u$ vitchy`znyanij transportnij sferi. [Problems and prospects of introduction of information technologies in the domestic transport sphere]. Suchasna ekonomika: aktual ni problemy ta perspekty`vy' rozvy`tku: kolekty`vna monografiya. [Modern Economics: Current Issues and Prospects for Development: A Collective Monograph]. Kharkiv: NTMT, pp. 73-78.
11. Kalycheva N. Je., Jelaghin Ju. V. (2018). Naprjamy zabezpechennja efektyvnogho rozvytku zaliznychnogho transportu za rakhunok zastosuvannja instrumentiv marketynghu. [Areas of ensuring the effective development of railway transport through the use of marketing tools]. Jevropejsjkyj vektor modernizaciji ekonomiky: kreatyvnistj, prozoristj ta stalyj rozvytok: monoghrafija [European Economy Modernization Vector: Creativity, Transparency and Sustainable Development: a monograph]. Kharkiv, (in Ukrainian).

\title{
АРХІТЕКТУРА УПРАВЛІННЯ СТРАТЕГІЧНИМИ ЗМІНАМИ НА ПІДПРИЕМСТВІ ТА ХАРАКТЕРИСТИКА ЇЇ ЕЛЕМЕНТІВ
}

\author{
Приймак Н.С., к.е.н., доцент (ДонНУЕТ)
}

У статті розглянуто зміст прочесу управління стратегічними змінами через розкриття його архітектури. Визначено, щя управління стратегічними змінами на підприємстві включає наступні етапи: усвідомлення чинної стратегї підприємства, ї̈ відповідності місії, баченню та стратегічним иілям в умовах безперервного тиску зовнішнього середовища та динамізму складових внутрішнього середовища; підготовка стратегічних змін; розробка стратегічних змін на підприємстві; реалізація стратегічних змін; контроль та закріплення стратегічних змін.

Ключові слова: стратегічні зміни, управління стратегічними змінами, архітектура управління стратегічними змінами, менеджмент змін, стратегічний менеджмент.

\section{АРХИТЕКТУРА УПРАВЛЕНИЯ СТРАТЕГИЧЕСКИМИ ИЗМЕНЕНИЯМИ НА ПРЕДПРИЯТИИ И ХАРАКТЕРИСТИКА ЕЕ ЭЛЕМЕНТОВ}

\author{
Приймак Н.С., к.э.н., доцент (ДонНУЭТ)
}

В статье раскрыты составляющие прочесса управления стратегическими изменениями через раскрытие его архитектуры. Определено, что управление стратегическими изменениями на предприятии включает следующие этапь: осознание действующей стратегии предприятия, ее соответствия миссии, видению и стратегическим иелям в условиях непрерывного давления внешней среды и динамизма составляющих внутренней средыг; подготовка стратегических изменений; разработка 
стратегических изменений на предприятии; реализация стратегических изменений; контроль и закрепление стратегических изменений.

Ключевые слова: стратегические изменения, управление стратегическими изменениями, архитектура управления стратегическими изменениями, менеджмент изменений, стратегический менеджмент.

\title{
ARCHITECTURE OF MANAGEMENT OF STRATEGIC CHANGES AT THE ENTERPRISE AND CHARACTERISTICS OF ITS ELEMENTS
}

\author{
Priymak N.S., Ph.D., associate professor (DonNUET)
}

Strategic activities - a process that implements system management and strategic management, directing the attainment of strategic business goals in the minds of the active consumption of the domestic and middle environment. Management of strategic assets, such as being a process, folding, an immanent real, like a vimaga, an element of architecture, and architecture management. The architecture of managing strategic assets on the basis of management has been imposed on the integrated circuit of the management scheme, so that more correct correlation procedures are used, which can be locked in the strategic management loop by means of strategic access. It is marked that the management of strategic assets for the future includes the offensive: the improvement of the strategic strategy, the average economy, and the strategic goals in the middle of the year. preparation of strategic zmin; rozrobka strategic zmin on pidprimemstvi; Realization of strategic reserves; control and closure of strategic reserves.

An important element of architecture is closed assembly, including inclusion, initialization and implementation. Initialization of strategic reserves for the transfer of funds during the transfer of all the management of strategic loans for the strategic management process, giving the status of "strategic until the weekend" within the framework of the functional Declaration of the results of the strategic reserves of the transfer of third-party results of the strategic results of the final result, the closure of official documents and the instructions for the business. Implementation of the results of strategic changes of transmission of victoria at the base of elements for scribble and praise of strategic and state decisions on business.

Keywords: strategic change, strategic change management, strategic change management architecture, change management, strategic management.

Постановка проблеми. В сучасних умовах політичної нестабільності, економічної кризи, динамізму ринків та внутрішньої економічної нестабільності діяльності підприємств, управління стратегічними змінами повинне розглядатися підприємствами як нова перспектива ефективного ведення бізнесу, шлях до набуття та збереження позицій лідерства на ринку залізорудної сировини України та зовнішніх цільових ринках. 3 цією метою підприємства змушені виконувати ряд претензійних вимог, які перед ними висуває довкілля для забезпечення досягнення цілей змін та бажаного стратегічного стану. Однією із таких вимог $\epsilon$ напрацювання ефективного механізму управління стратегічними змінами, заснованого на єдиному стратегічному підході та баченні системи менеджменту порядку досягнення цілей стратегічних змін.

Аналіз останніх досліджень $i$ публікацій. Питання ефективного забезпечення управління стратегічними змінами досліджувалися широким колом закордонних науковців, до числа яких належать I. Адизес [1], I. Ансофф [2], 
Р. Джейкобс [3], I. Ретолаза, Е.Камерон, М. Грін [4], Дж. П. Коттер [5], К. Левін [11]та інші. Також аспекти управління стратегічними змінами та їх реалізація в умовах вітчизняного наукового простору вивчаються українськими науковцями, серед яких О.В. Хаджинова, Г.О. Швіндіна, О.Ю. Гусєва [6], Г. В. Осовська, О. А. Осовський [7], Є.Л. Гринь , С.Г. Турчіна [8], Андрущенко [9], Ю.Ю. Ступіна, Н.О. [10] та інші.

Виділення невирішених частин загальної проблеми. Проте, незважаючи на значну кількість напрацювань у сфері управління стратегічними змінами, єдиного підходу (архітектури) та змістового наповнення етапів управління даним процесом науковцями не запропоновано, a тому, дане питання вимагає подальшого розвитку та обгрунтування.

Метою даної статті є обгрунтування архітектури управління стратегічними змінами на підприємстві в умовах функціонування системи стратегічного менеджменту та iї інтегрованої складової - менеджменту змін.

Виклад основного матеріалу дослідження. Функціонування системи стратегічного менеджменту підприємства стикається із проблемами впровадження, оцінки та обгрунтування стратегічних змін в рамках реалізації обраної стратегії функціонування. Стратегічні зміни - це сукупність процесів, реалізованих системою менеджменту змін та стратегічного менеджменту, спрямованих на досягнення стратегічних цілей підприємства в умовах активного впливу зовнішнього та внутрішнього середовища діяльності.

Управління стратегічними змінами, як будь-який процес, $\epsilon$ складним, іманентним явищем, яке вимагає обгрунтування його елементів, тобто архітектури управління.

$$
\text { Архітектура управління }
$$

стратегічними змінами на підприємстві наведена на рис. 1. у вигляді комплексної схеми управління, тобто сукупності кореляційних процедур та прийомів, які застосовуються в контурі стратегічного управління 3 метою досягнення цілей стратегічних змін.

Архітектура

управління стратегічними змінами на підприємстві представлена у вигляді інтегрованих у єдиний управлінський простір відносно самостійних управлінських етапів, та самостійних управлінських циклів. Проте, допустимим $\epsilon$ скорочення кількості управлінських дій (за потреби чи за рішенням керівника підприємства та/чи керівника команди змін).

$$
\text { Архітектура управління }
$$

стратегічними змінами на підприємстві включає наступні управлінські етапи:

1-й: усвідомлення чинної стратегії підприємства, iї відповідності місіі, баченню та стратегічним ціілям в умовах безперервного тиску зовнішнього середовища та динамізму складових внутрішнього середовища, у синергійному прояву яких відбивається необхідність здійснення стратегічних змін. Даний етап містить сукупність кореляційних процедур стратегічного менеджменту з моніторингу досягнення стратегічних цілей та їх інкреминації стратегічним умовам діяльності. На підприємствах із розвинутою системою стратегічного менеджменту даний етап $\epsilon$ імплементованою складовою циклу стратегічного менеджменту.

На даному етапі система стратегічного менеджменту визначається із необхідністю та терміновістю провадження стратегічних змін. 


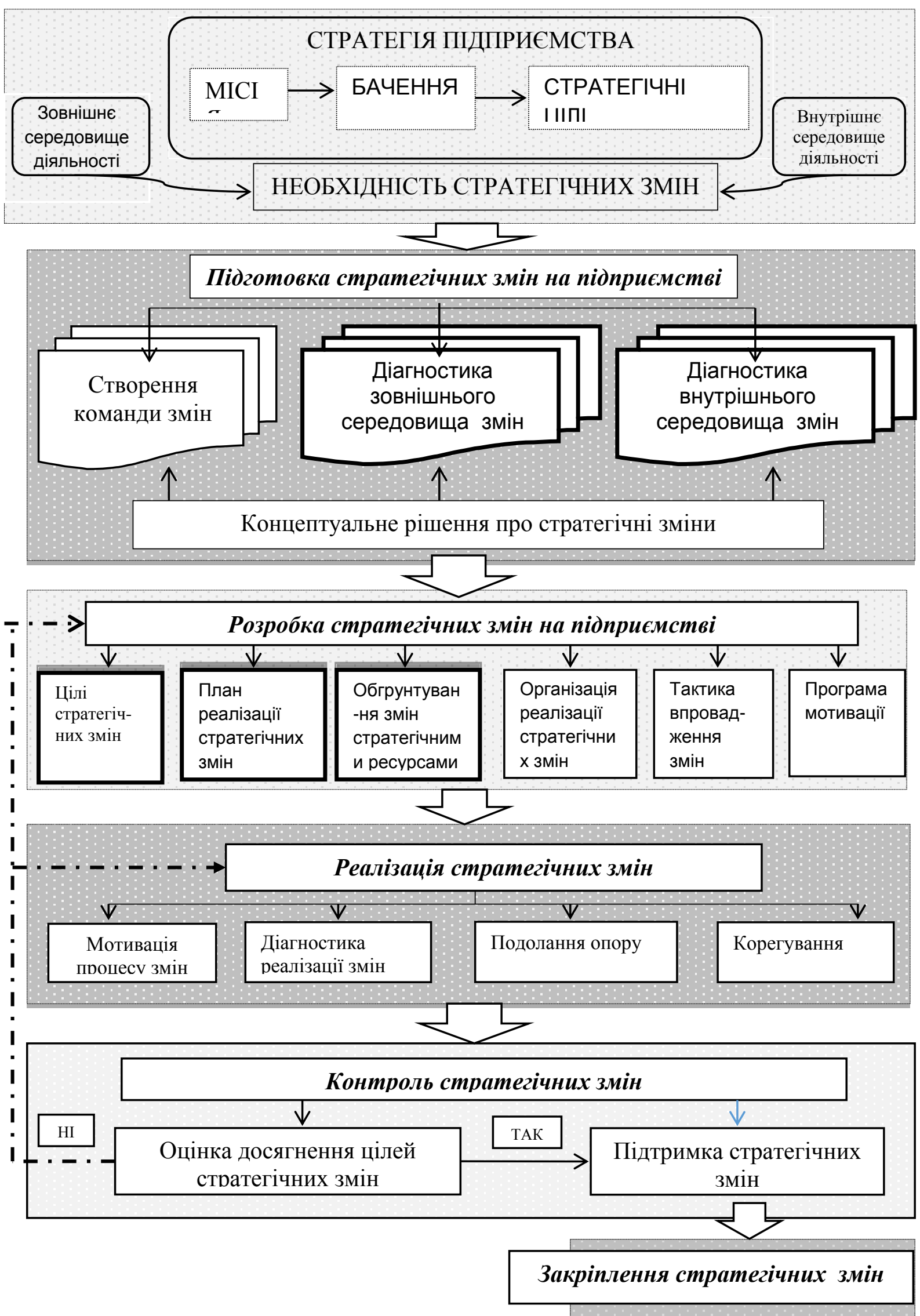

Рис. 1. Архітектура управління стратегічними змінами на підприємстві (складено автором на основі $[2 ; 8 ; 9 ; 10 ; 11])$ 
2-й: підготовка стратегічних змін на підприсмстві. На даному етапі відбувається безпосереднє створення команди стратегічних змін, визначення особи, відповідальної за їх розробку, реалізацію та ініціалізацію на підприємстві. Це може бути як окрема особа, що має достатню кваліфікацію та досвід в сфері управління стратегічними змінами, так і керівник підприємства. Команда змін формується 3 числа провідних фахівців функціональних підрозділів підприємства.
За потреби, на різних етапах управління залучаються сторонні виконавці - зовнішні агенти змін. Головна мета даного етапу вибір напрямків стратегічних змін та окреслення їх цілей.

3-й: розробка стратегічних змін на niдприємстві. Даний етап управління стратегічними змінами можна представити у вигляді реалізації комплексу підсистем управління розробкою стратегічних змін на підприємстві (рис. 2).

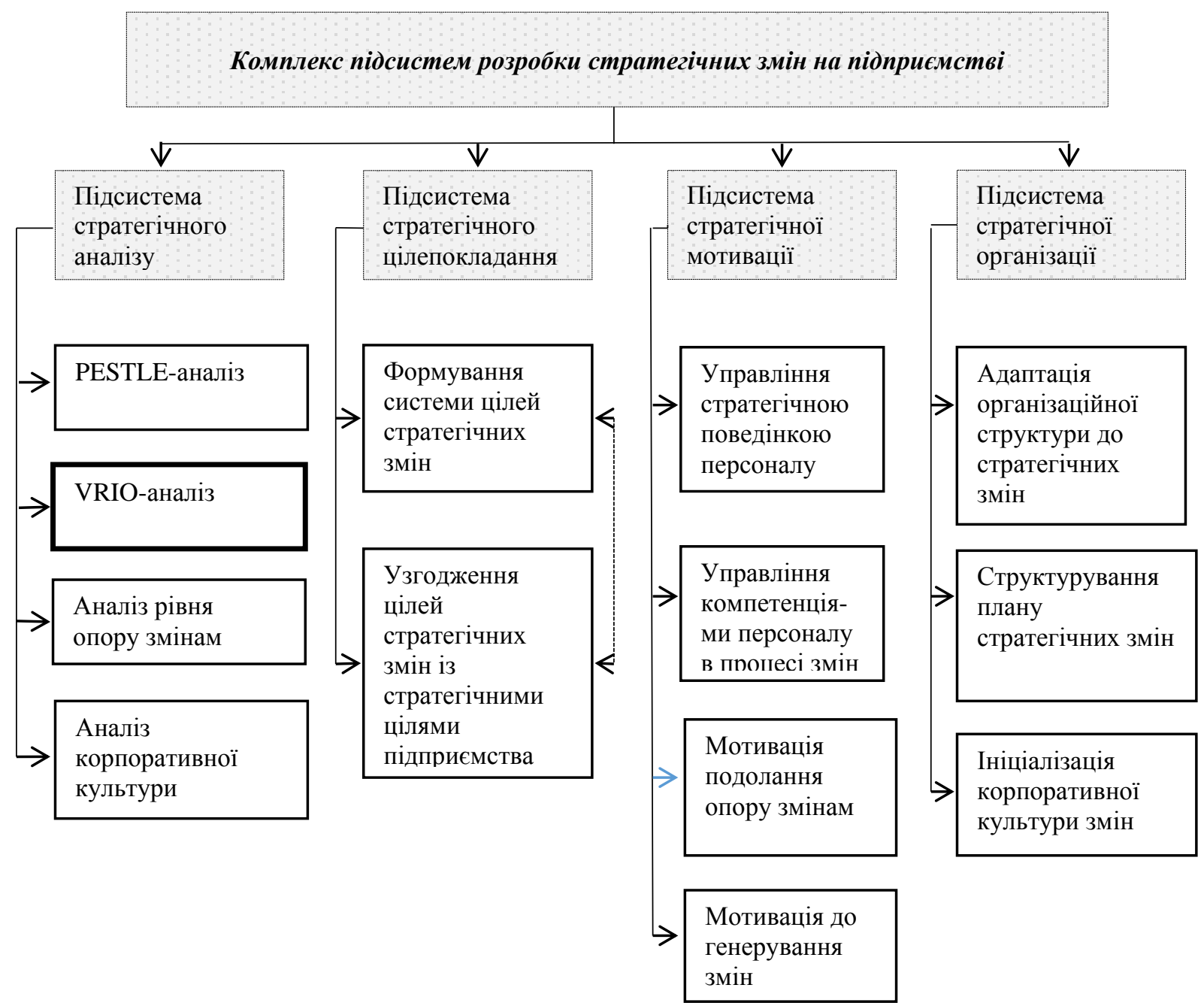

Рис. 2. Комплекс підсистем управління розробкою стратегічних змін на підприємстві (складено автором)

Підсистема стратегічного аудиту має на меті формування пулу інформації щодо рівня стратегічних можливостей змін підприємства та стану стратегічних ресурсів і внутрішнього потенціалу змін, їх достатності для забезпечення стратегічних змін та реалізації в певних умовах ринку та середовища діяльності. Також дана підсистема відповідає за визначення рівня опору змінам (внутрішнього та зовнішнього) та аналіз корпоративної культури по відношенню до змін. 
Досягнення мети забезпечується через систему внутрішнього та зовнішнього стратегічного аудитів.

\section{Підсистема}

стратегічного

цілепокладання відповідає за формування та формулювання цілей стратегічних змін, їх відображення у ключових документах та забезпечення їх когерентності із загальними стратегічними i тактичними цілями підприємства. Ефективне цілепокладання $\epsilon$ запорукою вдалої реалізації стратегічних змін.

Підсистема стратегічної мотивації забезпечує управління стратегічною поведінкою та компетенціями персоналу на всіх стадіях стратегічних змін, реалізацію механізмів мотивації змін, подолання опору та генерування стратегічних змін.

Підсистема стратегічної організації включає: адаптацію організаційної структури та організаційного дизайну до стратегічних змін, розробку та структурування плану стратегічних змін, ініціалізацію корпоративної культури сприяння змінам на підприємстві.

Адаптація організаційної структури та організаційного дизайну до стратегічних змін включає інтегрування команди стратегічних змін до іiї складу, справедливий та оптимальний розподіл праці в ході розробки та реалізації стратегічних змін, введення у функціональні обв'язки спеціалістів функцій реалізації змін при дотриманні субординації та ієрархічності як ключових функцій реформування організаційних структур та організаційного дизайну.

4-й: реалізачія стратегічних змін на підприємстві. Даний етап управління стратегічними змінами включає:

- мотивацію персоналу, задіяного в процесі стратегічних змін. Слід відзначити, що даний вид мотиваційного впливу на персонал (суб’єктів, учасників процесу стратегічних змін) носить підтримуючий та попереджувальний характер. Його мета - підтримка «режиму» змін, зацікавленості у результатах змін чи їх удосконаленні.
- проміжну діагностику реалізації цілей стратегічних змін, перебігу змін, їх ресурсного забезпечення та пошук шляхів усунення відхилень. Проміжна діагностика реалізації стратегічних змін на підприємстві є: різновидом контрольних функцій системи управління стратегічними змінами; інструментом визначення напрямків коригування програми стратегічних змін для запобігання можливих відхилень результатів змін через відхилення у параметрах підсистем розробки стратегічних змін та їх реалізації; джерелом інформації для керівника команди стратегічних змін щодо перебігу процесів їх реалізації та виконання ключових індикаторів результативності; підставою, базисом корегування процесу реалізації стратегічних змін на підприємстві (у разі виявлення значних відхилень).

5-й: контроль стратегічних змін на niдприємстві передбачає моніторинг досягнення стратегічних цілей змін та їх відповідності загальним стратегічним цілям підприємства.

Контроль стратегічних змін - це функція команди змін, метою якої $\epsilon$ спостереження та оцінювання процесу перебігу стратегічних змін через встановлення зворотного зв'язку із суб'єктами та об'єктами стратегічних змін, а також із зовнішнім середовищем підприємства. Основні завдання даного етапу: оцінка досягнення цілей стратегічних змін, а також їх відповідності цілям стратегії підприємства; вчасна ідентифікація відхилень результатів стратегічних змін від їх бажаного стану, виявлення причин їх виникнення; оцінка ризиків, виникнення яких пов'язане iз невідповідністю результатів стратегічних змін та їх цільового фокусу, обгрунтування заходів 3 їх мінімізації; розробка напрямків підтримки стратегічних змін на підприємстві (у випадку їх відповідності поставленим цілям). 
У випадку, якщо результати реалізації стратегічних змін задовольняють цілям, відбувається перехід на останній етап управління стратегічними змінами - закріплення стратегічних змін на підприємстві. Сутність даного етапу управління полягає у застосуванні ряду управлінських процедур, спрямованих на фіксацію на підприємстві та подальше нарощування результатів реалізації стратегічних змін.

Структурні елементи системи управлінського закріплення стратегічних змін на підприємстві звідяться до наступних: 1) ініціалізація стратегічних змін на підприємстві (в першу чергу, у процеси та документацію); 2) декларування та поширення результатів стратегічних змін через контактні аудиторії підприємства та коло стейкхолдерів; 3) імплементування результів реалізації стратегічних змін в діяльність підприємства; 4) мотивація участі персоналу.

Висновок.

Таким чином, управління стратегічними змінами як самостійний процес менеджменту змін на підприємстві вимагає реалізацію п'яти етапів управлінського циклу. Мета реалізації наведеної архітектури управління стратегічними змінами - не тільки досягнення поставлених системою менеджменту підприємства цілей стратегічних змін, але й збереження патерних досягнень від їх реалізації у довгостроковій перспективі на ринку, що забезпечується шляхом реалізації етапу закріплення стратегічних змін, ігнорування кого може привести до неефективного досягнення цілей стратегічних змін та втрати їх актуальності для підприємства.

\section{ПЕРЕЛІК ВИКОРИСТАНИХ ДЖЕРЕЛ}

1. Адизес И. Управляя изменениями/ И. Адизес. - СПб. : Питер, 2008. - 224 с.
2. Ансофф И. Стратегическое управление/ И. Ансофф. - М. : Экономика, 1989. - $201 \mathrm{c}$.

3. Джейкобс Р. Стратегические перемены в реальном времени: Эффективное внедрение метода стратегических перемен - путь к успеху : пер. с англ. / Р. Джейкобс. Днепропетровск: Баланс-Клуб, 2004. - С. 26.

4. Cameron E.Making Sense of Change Management : A Complete Guide to the Models, Tools \& Techniques of Organizational Change, 2d ed / E. Cameron, M. Green // Kogan Page. -2009. -384 p.

5. Коттер Дж. П. Впереди перемен/ Джон П. Коттер; [пер. с англ.]. - М.: ЗАО"Олимп-Бизнес", 2011. - 256 с.

6. Гусєва О.Ю. Управління стратегічними змінами: теорія i прикладні аспекти: Монографія / О. Ю. Гусєва. - Донецьк: Вид-во «Ноулідж» (донецьке відділення), 2014. - 395 с.

7. Осовська Г. В., Осовський О. А. Управління стратегічними змінами на підприємстві / Г. В.Осовська, О. А. Осовський // Ефективна економіка. 2018.- № 12. - Режим доступу: http://www.economy.nayka.com.ua/?op=1\&z $=6730$

8. Турчіна С. Г. Управління змінами в контексті стратегічного розвитку підприємств / С. Г. Турчіна // Вісник Сумського національного аграрного університету. Серія: Економіка i менеджмент. - 2016. - Вип. 1. - С. 11-15.

9. Андрущенко Н.О. Роль та значення сучасної системи управління змінами як одного 3 факторів стрімкого розвитку вітчизняних підприємств торгівлі / Н.О. Андрущенко // Глобальні та національні проблеми економіки [Електронне наукове фахове видання]. 2015.- Випуск 5. - с. 288-291. - Режим доступу : http://global-national.in.ua/issue-52015/13-vipusk-5-traven-2015-r/798andrushchenko-n-o-rol-ta-znachennyasuchasnoji-sistemi-upravlinnya-zminami- 
yak-odnogo-z-faktoriv-strimkogo-rozvitkuvitchiznyanikh-pidpriemstv-torgivli

10. Ступіна Ю. Ю. Концептуальні положення формування організаційноекономічного забезпечення управління змінами на підприємствах машинобудування / Ю. Ю. Ступіна, Ю. В. Ус // Бізнес Інформ. - 2016. - № 5. - С. 214 219.

11. Lewin K. Feild Theory in Social Science / K. Lewin. - New York: Harper \& Row, 1951. -346 p.

\section{REFERRENCES}

1. Adizes I. (2008). Upravlyaya izmeneniyami [Managing Change]. SPb.: Piter, 224 [in Russian].

2. Ansoff I. (1989). Strategicheskoye upravleniye [Strategic management]. M.: Economics [in Russian].

3. Jacobs R. (2004). Strategicheskiye peremeny $v$ real'nom vremeni: Effektivnoye vnedreniye metoda strategicheskikh peremen - put' $k$ uspekhu [Real-time strategic change: Effective implementation of the strategic change method - the path to success]. Dnepropetrovsk: Balance Club [in Russian].

4. Cameron E. (2009). Making Sense of Change Management: A Complete Guide to the Models, Tools \& Techniques of Organizational Change, 2d ed. Kogan Page.

5. Kotter J.P. (2011). Vperedi peremen [Ahead of change]. M.: CJSC OlympBusiness [in Russian].

6. Husyeva O.YU. (2014). Upravlinnya stratehichnymy zminamy: teoriya i prykladni aspekty [Strategic Change Management: Theory and Applied Aspects]. Donetsk: Knowledge Publishing House (Donetsk Branch) [in Ukrainian].

7. Osovs'ka H. V. \& Osovs'kyy O. A. (2018). Upravlinnya stratehichnymy zminamy na pidpryyemstvi [Managing strategic change at the enterprise]. Efektyvna ekonomika - Effective economy, 12. Retrieved from: http://www.economy.nayka.com.ua/?op=1\&z $=6730$ [in Ukrainian].

8. Turchina S. H. (2016). Upravlinnya zminamy v konteksti stratehichnoho rozvytku pidpryyemstv [Managing change in the context of strategic enterprise development] Visnyk Sums'koho natsional'noho ahrarnoho universytetu. Seriya: Ekonomika $i$ menedzhment - Bulletin of Sumy National Agrarian University. Series: Economics and Management, 1, 11-15. [in Ukrainian].

9. Andrushchenko N.O. (2015). Rol' ta znachennya suchasnoyi systemy upravlinnya zminamy yak odnoho $\mathrm{z}$ faktoriv strimkoho rozvytku vitchyznyanykh pidpryyemstv torhivli [The role and importance of the modern system of change management as one of the factors of rapid development of domestic trade enterprises]. Hlobal'ni ta natsional'ni problemy ekonomiky - Global and national problems of economy, 5, 288291. Retrieved from: http://globalnational.in.ua/issue-5-2015/13-vipusk-5-

traven-2015-r/798-andrushchenko-n-o-rol-taznachennya-suchasnoji-sistemi-upravlinnyazminami-yak-odnogo-z-faktoriv-strimkogorozvitku-vitchiznyanikh-pidpriemstv-torgivli [in Ukrainian].

10. Stupina YU. YU. (2016). Kontseptual'ni polozhennya formuvannya orhanizatsiyno-ekonomichnoho zabezpechennya upravlinnya zminamy na pidpryyemstvakh mashynobuduvannya [Conceptual provisions for the formation of organizational and economic support for change management in mechanical engineering enterprises]. Biznes InformBiznes Inform, 5, 214-219 [in Ukrainian].

11. Lewin K. (1951). Feild Theory in Social Science. New York: Harper \& Row, $346 \mathrm{p}$. 